\title{
State Debt Management in the Russian Federation in Modern Socio-Economic Conditions
}

\author{
Atanasovska Yu.V. ${ }^{1}$ Sanginova L.D. ${ }^{2}$ Balynin I.V. ${ }^{3, *}$ \\ ${ }^{1}$ International Slavic university "G.R. Derzhavin", Skopje, 1000, Republic of Macedonia \\ ${ }^{2}$ Financial University under the Government of the Russian Federation, Moscow, 125167, Russian Federation \\ ${ }^{3}$ Financial University under the Government of the Russian Federation, Moscow, 125167, Russian Federation \\ *Corresponding author. Email: igorbalynin@mail.ru
}

\begin{abstract}
The article is devoted to the problems of state debt control in the Russian Federation at the present stage of its development. Based on the conducted analysis, an estimation of the effectiveness of state debt control in the Russian Federation was made by means of calculating a number of indicators which characterize this process qualitatively and quantitatively. A comparative analysis with a number of other countries has shown that Russia's state debt is one of the lowest in the world. But at the same time, it is important to ensure the effectiveness of state debt management to provide the socio-economic development of the Russian Federation. In the framework of recommendations to solve the identified problems, special attention is paid to the debt policy strategy actualization, constant publication of stress testing results, and modernizing the management of state guarantees.
\end{abstract}

Keywords: state debt, debt sustainability, coronavirus, stress testing, debt policy, budget risks

\section{INTRODUCTION}

Issues of public finance management are priorities for the countries of the world community nowadays. Usually economic growth requires significant investments which are provided through borrowings, therefore it can lead to an increase in debt obligations publicly-legal education, the debt burden on the Federal (Central) budget and therefore proper state debt management is needed.

Based on the supervising principle of state debt management prepared by experts of the International Monetary Fund and the World Bank in 2014, it should be noted that effective public state management means the following: first, the possibility to find the necessary amount of funds for public law education on a loan, repayment and fee basis on acceptable terms which do not increase the cost of servicing public debt in the medium and long term significantly, and do not reduce the debt sustainability of public law education.

This means that the public legal entity has the ability to service both current maintenance costs and repay the principal amount of debt fully and timely, and the structure of debt obligations does not have any market or currency risk, or refinancing risk.

\subsection{Related Work}

Much attention is paid to the issues of debt management in foreign scientific literature. In particular, B.A.
Badertscher, D. Givoly, S.P. Katz, H. Lee [1] studied issues associated with the state debt cost, and R. Rudyk paid his attention to the presence of the influence of macroeconomic factors on the transformation of the state's debt policy [2]. At the same time, we connected this problem with the achievement of economic goals.

T. Goncalves, C. Gaio, C Lelis [3] studied European states' experience; A. Zahariev, M. Zveryakov, S. Prodanov, G. Zaharieva, P. Angelov, S. Zarkova, M. Petrova [4], M. Delgado-Tellez, J.J. Perez [5], H. Dagdeviren, J. Balasuriya, S. Luz, A. Malik, H. Shah [6], A.S.K. Rathnayake [7], G.C. Montes, I. Souza [8], O. Small, L. Brown, G. S.Y. Canavire-Bacarreza [9], A.L. Lau, Tan, C.Y. Liew [10] considered the experience of Italy, Greece, Spain, Great Britain, Sri Lanka and Brazil, Malaysia.

\subsection{Our Contribution}

It is possible to assess the ability of a sovereign borrower to manage public debt according to the methodology for assessing the effectiveness of public debt management (DeMPAT), developed by the World Bank specified in 2015, which is carried out in five areas and includes 14 qualitative indicators in 33 dimensions

The first direction of assess the efficiency of state debt management according to the methodology of DeMPAT is: "Management and Strategy", where analysis of "Debt Management Strategy" is performed which along with a 
review and evaluation of indicators such as "Legal Basis", "Control Structure", "Debt Reporting and debt Management Operations Evaluation", "Audit". The first estimated measure of this indicator is the "quality of the debt management strategy document", which, should contain a medium-term debt management strategy with a high level of public debt management efficiency (value A), approved by the state's highest executive authority. It is a plan which is expected to be implemented in the medium term in order to ensure the desired structure of the debt portfolio, representing the preferences of management bodies in terms of the cost-risk ratio. According to the developers of DeMPAT, it should specify the goals of debt management and be focused primarily on an actual risk control, inherent in the debt portfolio, in particular, possible variations in a debt service cost and their consequences for the budget. In addition, methodical recommendations indicate the need for annual updating of this document. In Russian practice, the main directions of the state debt policy of the Russian Federation for a 3-year period are being developed (they were last adopted in 2017), but this document is not updated annually and is not approved by the Supreme executive body of the Russian Federation. Therefore, it does not take into account the impact of changes in external and internal factors that may affect the risks of managing debt obligations. The directions and measures of debt management developed in the document are not binding, since this document is not approved by the Russian Federation government. In addition, this document does not specify the risks associated with the state debt control of the Russian Federation, the impact of the proposed measures on the amount of expenditures for servicing the state debt of the Russian Federation is not estimated under the influence of external and internal factors. All above mentioned facts indicate an insufficiently high quality of the developed strategy for the state debt control in the Russian Federation.

It should be noted that the document approved by the Russian Ministry of Finance - "Main directions of budget, tax, customs and tariff policy for the next financial year and for the planning period" is updated annually in Russia, taking into account changes in internal and external conditions. However, it represents only the planned indicators of the volume and proportion of the Russian Federation's state debt to GDP (\%), its composition and structure by type of debt obligations, as well as by currency. Therefore, there is no update on the types of borrowings, the goals of state guarantees are not disclosed, the problems and prospects of the debt portfolio structure are not analyzed depending on changes in internal and external conditions; there is no risk assessment and debt sustainability estimation.

It should be noted that certain targets characterizing the effectiveness of state debt control in the Russian
Federation are recorded in the State program "State finance management and financial market regulation, which are updated annually, but the risk estimation of state debt and financial assets control in the Russian Federation is also absent.

While developing a state debt control strategy, it is important for managers to evaluate the impact of different scenarios on indicators of aggregate expenditures of debt servicing, sensitivity to changes in interest rates and exchange rates, quantify the optimal debt structure (the ratio of external debt to domestic debt, the currency structure of debt, the maximum ratio of floating-rate debt to fixed-rate debt, etc.) under different scenarios, determine the duration of the portfolio, etc. An annual update of the developed state debt control strategy is mandatory if it is developed for a three-year period. The official publication also testifies to the effective management of the state's debt obligations, since it is possible to exercise public control over the declared and actually achieved indicators of debt control in this case.

In our opinion, an assessment of the effectiveness of state debt control should be related to the analysis of the limit value of state debt with regard to GDP, since this parameter reflects the effectiveness of state debt control quantitatively. The ratio of state debt to GDP is one of the main indicators that assesses the state's debt sustainability, recommended by the IMF and ISSAI, measures a debt level associated with the state's economic activity. When calculating it, it assumes that the entire volume of GDP can be used to cover debt obligations, and it assesses the potential solvency of the state.

\section{BACKGROUND}

\subsection{Results}

Table 1 shows the values of state debt to GDP ratios in dynamics for 2014-2019 for a number of countries. Table 1 shows that Russia has very low public debt-to-GDP values compared to other countries.

As figure 1 shows, despite the absolute increase in state debt servicing expenditures in recent years in the Russian Federation, its relative indicator does not exceed the established values and is less than $5 \%$ of Federal budget expenditures or $0.8 \%$ of GDP in 01.01.2019. This indicator is low compared to other countries. For example, almost $25 \%$ of the Federal budget in the United States is spent on servicing debt obligations, which already exceeds their spending on the defense complex. 
Table 1 Indicator dynamics "Ratio of state debt to GDP, in \% for 2014-2019 years

\begin{tabular}{|l|c|c|c|c|c|}
\hline \multicolumn{1}{|c|}{ Country } & $\mathbf{2 0 1 4}$ & $\mathbf{2 0 1 5}$ & $\mathbf{2 0 1 6}$ & $\mathbf{2 0 1 7}$ & $\mathbf{2 0 1 8}^{*}$ \\
\hline Russia & 13,1 & 13,2 & 12,9 & 12,6 & 16,5 \\
\hline Austria & 101,87 & 101,29 & 101,46 & 95,15 & 89,82 \\
\hline Germany & 85,55 & 81,40 & 78,51 & 74,22 & 70,39 \\
\hline United Kingdom (Great Britain) & 113,26 & 112,80 & 122,47 & 119,86 & 116,56 \\
\hline France & 120,16 & 120,83 & 123,66 & 122,79 & 122,12 \\
\hline Greece & 181,24 & 183,00 & 186,25 & 188,76 & 193,00 \\
\hline Japan & 238,18 & 237,09 & 235,76 & 234,04 & 238,73 \\
\hline
\end{tabular}

Source: Rosstat; * according to information Organization for economic cooperation and development

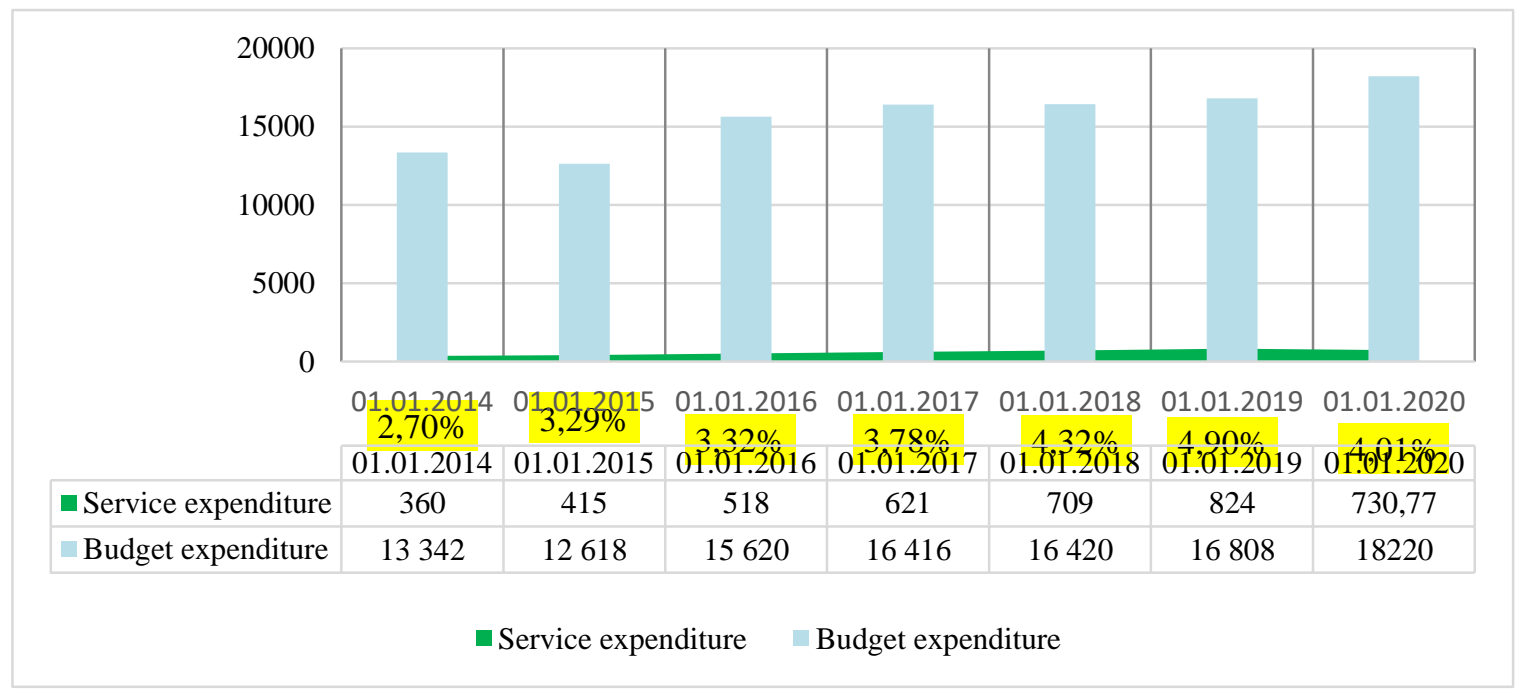

Figure 1 Federal budget expenditures ratio on state debt servicing in the structure of Federal budget expenditures, in billion rubles. Source: compiled and calculated according to the Ministry of Finance of the Russian Federation (minfin.ru), according to the Federal Treasury (roskazna.ru) (date of request: 27.10. 2019)

While analyzing the effectiveness of public debt management, it is important to evaluate the ratio of GDP growth rates to public debt in order to determine the effectiveness of the use of borrowed funds. As it can be seen from table 2, starting from 2016, the growth rate of GDP in the Russian Federation is higher than one of state debt. So, in 2016 , GDP grew by $2 \%$ more than the national debt, in 2017 - by $3 \%$, and in 2018 - by $5 \%$.
The next indicator which characterizes the state debt management effectiveness is the state's ability to pay for debt obligations. This indicator is recorded in the State program as "State debt Ratio of the Russian Federation to Federal budget revenues", which should not exceed 100\%. From Figure 3, we can state that the Russian Federation has a high solvency in relation to creditors, since the volume of annual Federal budget revenues is significantly higher than the size of its public debt. 


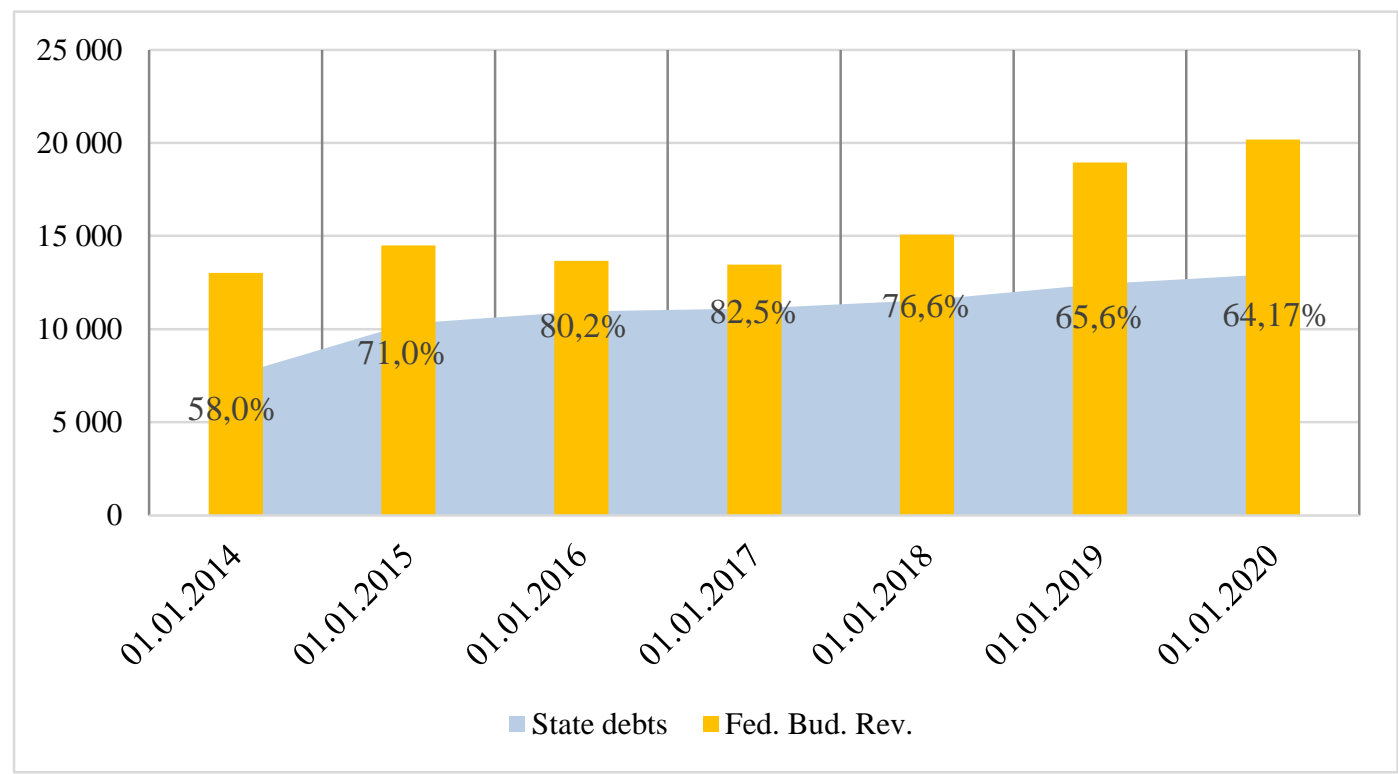

Fiigure 2 State debt ratio of the Russian Federation to Federal budget revenues, in billion rubles. Source: compiled and calculated according to the Ministry of Finance of the Russian Federation (minfin.ru), according to the Federal Treasury (roskazna.ru) (date of request: 27.10. 2019)

\subsection{Discussions}

Despite the fact that since 2017 in Russia there has been a constant increase in the level of state debt of the Russian Federation, both in absolute value and in relation to gross domestic product - in 2021 year it is planned at a rate of $16.5 \%$. However, it should be noted that there is a margin of safety to reach the limit of $20 \%$ of GDP, which is set in the State program of the Russian Federation "State finance management and regulation of financial markets" (Next State program). On the period of 01.01.2019 state debt of the Russian Federation is the lowest in relation to GDP in comparison with many developed and developing countries. For developing countries, this value should not exceed $50 \%$ of GDP. As it can be seen from the figures for this indicator according to the recommendations of the IMF, the Russian Federation has a 3-multiple margin of safety, which indicates that there are no problems in managing public debt, high solvency, both in the current period and in the near future.

The obtained results of comparing economic growth rates and an increase rate of the state debt of the Russian Federation allow to give a positive assessment, since the economy is growing faster than the national debt of the Russian Federation, which means that the state debt level is at a safe value, and there is no threat of its negative impact on the socio-economic development of the country. This indicates an effective state debt control. At the same time, it should be taken into account that the state debt of the Russian Federation does not include hidden obligations (debt obligations of the Russian Federation subjects, obligations of legal entities with a share of the state in the authorized (share capital), i.e. the so-called hidden (implicit) obligations. When developing a debt policy strategy, managers should reveal the impact of hidden (implicit) obligations on the state debt status.

An important indicator of the effectiveness of state debt control is the ratio of debt service expenditures to Federal budget expenditures (or GDP), since it indicates the level of unproductive ones. Therefore, both the IMF documents and the State program regulate this indicator. At the same time, according to the recommendations of the IMF, its value should be no more than $10 \%$ of GDP for developing countries and no more than 15\% of GDP for developed economies. According to the State program, the value of this indicator should not exceed $10 \%$ of Federal budget expenditures. Therefore, the limits on the amount of debt servicing expenditure in national legislation and international acts have different basic characteristics. In our opinion, because of the low value of debt servicing expenditures in Russia and taking into account that the source of payment of state debt servicing expenditures is the Federal budget, it is appropriate to assess the level of state debt servicing expenditures, namely, Federal budget ones.

Due to the absence of official statistics on the annual amount of payments to repay debt obligations, it is not possible to assess compliance with the target set in the State program, the ratio of the annual amount of repayment and state debt service per the volume of Federal budget revenues, which should be no more than $15 \%$.

The structure of the state debt of the Russian Federation from the position of currency risk is quite optimal, since the structure of the state debt of the Russian Federation is 
dominated by debt obligations denominated in the national currency - more than $75 \%$, which corresponds to the ratio of the share of the state internal debt of the Russian Federation in the total amount of public debt $(65 \%$ or more) set by the State program. The actual structure of the state debt of the Russian Federation indicates effective management of the state debt and low currency risks. In contrast to Russia, the structure of public debt in developing countries, as a rule, external debt occupies a significant part. For example, there is a large external debt in Brazil, Korea, India, and Belarus, which indicates that these countries have low debt sustainability.

In the structure of the state internal debt of the Russian Federation, the predominant share (more than $77-85 \%$ ) is occupied by debt obligations on state securities of the Russian Federation, i.e. the securitized part of the debt. This also demonstrates effective control of the Russian Federation's state debt, since most of the securities can be traded on the secondary market, and the issuer can buy back securities if they become expensive to maintain, i.e. manage the debt in its own interests.

Thus, in Russia, the guarantee goals in recent years have been aimed at stimulating the country's economic development, as well as supporting organizations with difficulties due to the consequences of crisis situations in the economy. At the same time, there is no standard practice yet, for example, for OECD member countries, a system of payment for guarantee support that directly links the cost of the guarantee received by the beneficiary to the risk level of the project (principal) that is supported. In addition, along with the assumed risks of performance of guarantee obligations, the provision and further administration of state guarantees is associated with other fixed costs which the Russian Federation is to perform as a guarantor.

The state external debt of the Russian Federation consists primarily of obligations on state securities denominated in foreign currency-Eurobonds $(75 \%)$. It should be emphasized that the Ministry of Finance of the Russian Federation regularly repurchases existing Eurobonds and issues new ones with more favorable conditions for the state, including in terms of reducing the coupon rate in order to maintain the liquidity of the market for these securities. The repurchase of previously issued bonds carried out by the Ministry of Finance of the Russian Federation in recent years not only reduces debt servicing costs, but also minimizes market risk and refinancing risk, which indicates effective management of the state external debt of the Russian Federation.

State guarantees of the Russian Federation in foreign currency take the second place in the structure of state external debt, accounting for $23 \%$. The absolute priority in providing state guarantees in foreign currency for the analyzed period was given to supporting the export of Russian high-tech products (more than $96 \%$ of the portfolio), which is evaluated positively. Such guarantees do not negatively affect the debt sustainability of the Russian Federation, which indicates the effective management of this part of the state external debt of the Russian Federation.
While analyzing the debt sustainability, the estimation of the state debt of a public legal entity to the volume of gold and foreign exchange reserves is used. According to the Central Bank of the Russian Federation the volume of international reserves of the Russian Federation equals 532,9 billion dollars of USA, while the state debt of the Russian Federation equals 12425 billion rubles, that indicates the Russian Federation is able to cover all debt obligations only at the expense of foreign exchange reserves, which exceeded 2.6 times. This amount of gold and foreign exchange reserves of the country is a guarantee of the issuer's solvency to creditors for obligations.

Thus, it should be noted that quantitative indicators, the assessment of the debt sustainability of the Russian Federation, the low level of public debt, the high solvency of the Russian Federation, the optimal structure of public debt that reduces market and currency risks, indicate a high level and efficiency of public debt management. At the same time, it is advisable to increase a number of qualitative indicators included in the assessment of the effectiveness of state debt management.

\section{CONCLUSION}

In our opinion, the main recommendations that ensure effective public debt management in the Russian Federation are:

1. Annual updating and specification of the main directions of the state debt policy, which will define the strategic directions of state debt management.

2. Possible changes in the cost of public debt servicing and risks in the event of changes in the structure of the debt portfolio should be assessed and publicly disclosed in this document, and acceptable expenditures and risks in public debt management should be analyzed, setting key indicators that are acceptable for the Russian Federation in the medium term.

3. The procedure for drawing up and maintaining a public debt management strategy of the Russian Federation should be made more clear and open.

4. The strategy of public debt management should be coordinated with the expected directions of monetary and fiscal policies.

5. When developing a debt policy strategy, debt managers should disclose the impact of hidden (implicit) obligations on the state debt status.

6. It is advisable to represent the results of conducted stress testing of the Russian Federation's public debt documentarily, taking into account the influence of external and internal factors.

7. It is important to present the target indicators of state debt management of the Russian Federation both for previous periods, for the reporting year, and for the next financial year and planning period. At the same time, the values of both planned indicators and actually achieved ones should be provided.

One of the ways to optimize the state external debt of the Russian Federation is to reduce its dollar component, which accounts for $97 \%$, and only $3 \%$ of liabilities are 
[7] A.S.K. Rathnayake, Sustainability of the fiscal imbalance and public debt under fiscal policy asymmetries in Sri Lanka, Journal of Asian economics.2020, V. 66.Paper 101161. DOI: 10.1016/j.asieco.2019.101161

[8] G.C. Montes, I. Souza, Sovereign default risk, debt uncertainty and fiscal credibility: The case of Brazil // North American Journal of Economics and Finance, 2020, V. 51, Paper UNSP 100851. DOI: 10.1016/j.najef.2018.09.009

[9] O. Small, L Brown, Canavire-Bacarreza, G. The fiscal policy response to public debt in developing countries, Contemporary economic policy, 2020, V. 38, Issue 1, pp. 155-165 DOI: 10.1111/coep.12432

[10] A.L. Lau, Tan, C.Y. Liew, The Asymmetric Link between Public Debt and Private Investment in Malaysia, Malaysian journal of economic studies, V.56, Issue 2, pp. 327-342 DOI: 10.22452/MJES.vol56no2.8

\section{REFERENCES}

[1] B.A. Badertscher, D. Givoly, S.P. Katz, H. Lee, Private Ownership and the Cost of Public Debt: Evidence from the Bond Market, Management science, 2019, V. 65, Issue: 1. pp. 301-326 DOI: 10.1287/mnsc.2017.2935

[2] R. Rudyk, Features of influence of macroeconomic measures of transformation on the state debt policy, Baltic journal of economic studies, 2015, V.1, Issue 1, pp. 147-153

[3] T. Goncalves, C. Gaio, C Lelis, Accrual mispricing: Evidence from European sovereign debt crisis, Research in International Business and Finance, 2020, V. 52 UNSP 101111. DOI: 10.1016/j.ribaf.2019.101111

[4] A. Zahariev, M. Zveryakov, S. Prodanov, G. Zaharieva, P. Angelov, S. Zarkova, M. Petrova, Debt Management Evaluation through Support Vector Machines: on the example of Italy and Greece, Entrepreneurship and Sustainability issues. 2020, V. 7, Issue 3, pp. 2382-2393. DOI: 10.9770/jesi.2020.7.3(61)

[5] M. Delgado-Tellez, J.J. Perez, Institutional and Economic Determinants of Regional Public Debt in Spain // Public finance review, 2020, V. 48, Issue 2, pp. 212-249. DOI: $10.1177 / 1091142120901672$

[6] H. Dagdeviren, J. Balasuriya, S. Luz, A. Malik, H. Shah, Financialisation, Welfare Retrenchment and Subsistence Debt in Britain, New political economy, 2020, V. 25. Issue 2., pp. 159-173. DOI: 10.1080/13563467.2019.1570102 